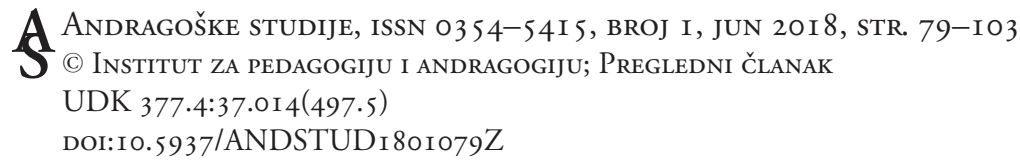

Tihomir Žiljak ${ }^{1}$

Open University Zagreb, Croatia

Nikša Alfirević ${ }^{2}$

Faculty of Economics, University of Split, Croatia

Jurica Pavičićc ${ }^{3}$

Faculty of Economics and Business, University of Zagreb, Croatia

Mario Vučić ${ }^{4}$

Agency for Vocational Education and Training and Adult Education, Croatia

\title{
The Promotion of Vocational and Adult Learning in Croatia: Results of a Policy Initiative and Generic Implications for Policy and Education Practice in South-East Europe ${ }^{5}$
}

\begin{abstract}
In this paper, the authors present and analyse a recent policy recommendation for the promotion of vocational and adult learning in Croatia. They also introduce arguments in favour of wider stakeholder participation and provide guidelines for the implementation of marketing principles in the promotion of learning. Generic implications for similar initiatives in South-East Europe are also identified.
\end{abstract}

Key words: lifelong learning, promotion, Croatia.

\footnotetext{
${ }_{1}$ Tihomir Žiljak, PhD is Head of the Department for Lifelong Learning, Development and EU Programs at Open University Zagreb, assistan professor at University of Zagreb, Croatia and University of Mostar, Bosnia and Herzegovina (tziljak@gmail.com).

${ }^{2}$ Nikša Alfirević, PhD is professor at Faculty of Economics, University of Split, Croatia and researcher at Scientific Centre of Excellence for School Effectiveness and Management (nalf@efst.hr).

${ }^{3}$ Jurica Pavičić, PhD is professor and vice-dean at Faculty of Economics and Business, University of Zagreb, Croatia and lead researcher at Scientific Centre of Excellence for School Effectiveness and Management (jpavicic@efzg.hr).

${ }^{4}$ Mario Vučić is assistant director for adult education development at Agency for Vocational Education and Training and Adult Education, Croatia (mario.vucic@asoo.hr).

${ }_{5}^{5}$ Authors would like to acknowledge support, received from the the Croatian Agency for Vocational Education and Training and Adult Education and the Croatian Scientific Center of Excellence for School Effectiveness and Management.
} 


\section{Introduction}

This study is based on a policy recommendation to relevant stakeholders in adult learning in Croatia (Vučić, Alfirević \& Pavičić, 2017), developed by a team of experts and advisors employed by the Agency for Vocational Education and Training and Adult Education (Agencija za strukovno i obrazovanje odraslih [ASOO]). As an integral part of a wider, EU-funded project for the promotion of adult learning in Croatia, the Agency for Vocational Education and Training and Adult Education provided an initiative and guidelines for a participative national effort to promote learning and education within Croatian society. The result of this effort is relevant for countries in the wider South-East European (SEE) region, both from the perspective of producing and implementing similar policy documents, as well as from reference to its more generic aspect on how to implement marketing and promotion principles in different fields of education.

\section{Analysis of the state of lifelong learning in Croatia}

\section{Lifelong and adult learning: definitions and policies}

There is a certain degree of ambiguity over how to define the contemporary concept of lifelong learning. Schuetze and Casey (2006) have identified four models associated with lifelong learning:

- the emancipatory model, promoting equality of opportunity and life chances for all (education for all);

- the cultural model, promoting the importance of self-realisation through learning (lifelong learning for self-fulfilment);

- the open society model, promoting the inclusion of minority groups and others in society who may be excluded for some reason (lifelong learning for everyone who wishes to participate);

- the human capital model, promoting lifelong learning for professional development and building skills needed in the workplace (lifelong learning for employability).

These different elements can, as Aspin and Chapman (2007, p. 34) have suggested, be connected into a triad which characterises the nature of lifelong learning:

- learning for economic progress and social development;

- learning for personal development and self-fulfilment; 
- learning for social inclusion, understanding and action in democratic processes.

In this model, lifelong learning is revealed as a process which covers every period of life, as well as every form of learning.

European and Croatian documents both draw a clear distinction between formal and non-formal education on the one hand, and informal learning on the other, as mentioned in the Memorandum on Lifelong Learning (EC, 2000), and the Action Plan on Adult Learning - It's never too late to learn (EC, 2006). The Adult Education Act (VRH, 2007) in Croatia outlines all the classifications, which are further defined in the Vocational Education Act (VRH, 2013a). Lifelong learning is listed in the Strategy of Education, Science and Technology as one of the foundations of the education system.

Adult education, representing the longest phase of lifelong learning, and continuous education, which may be more correctly designated as continuous vocational education and training, are concepts related to lifelong learning which also appear in public policy documents. Continuous education, or education and training engaged in after an individual has completed their regular formal education, is very common in Croatia, and draws on the same demographic as adult education (adults who have completed regular education). The connection between these two concepts is clearly expressed in the Croatian Bureau of Statistics' definition of adult education: "Adult Education is aimed at providing education for adults who have not obtained an adequate education in the course of regular schooling and those who want to get more of vocational education" (DZS, 2015).

The VET System Development Programme (2016 - 2020) (VRH, 2016a), adopted in September 2016, addresses initial and continuous vocational education. Lifelong education and continuous vocational education are here understood as synonyms, with the latter providing new vocational skills for the labour market. There is also a place for the development of non-vocational skills, which can play a part in increasing the effectiveness of the individual in the labour market. For example, developing reading literacy and encouraging reading in general are seen as component parts in the implementation of the 2015 National Strategy for the Encouragement of Reading, which is yet to reach adoption phase. Other strategies, such as volunteering as a form of lifelong learning, as mentioned in the National Strategy of Creating an Enabling Environment for Civil Society Development from 2012 to 2016 (VRH, 2012), also draw on the concept of lifelong learning, although to a lesser extent.

While a range of skills, competencies and areas of civic involvement are integral to the concept of lifelong learning since the Lisbon Process (2010), the ma- 
jor focus in Europe, which is reflected in Croatia, has been on the strengthening of competences for the labour market. When collecting data on lifelong learning, the Statistical Office of the European Union (Eurostat) monitors the participation of adults in lifelong education (ages 25 to 64) with particular emphasis on job requirements. In reaction to this, Nóvoa has suggested that the concept of lifelong learning is being transformed into a concept aimed solely at acquiring the right skills for the labour market (Nóvoa, 2013).

Considering this evidence, we can conclude that the concept of lifelong learning in the European Union and, subsequent to the adoption of the EU's key definition, Croatia, most frequently applies to adults who require skills to enter or improve their position in the labour market. All other forms of learning gain importance if they serve those main objectives. At the same time, it is necessary for regular education to create a firm foundation for lifelong learning, while learning outcomes for non-vocational education should encourage the development of civic involvement as well as innovativeness and entrepreneurial values.

\section{Socioeconomic context of adult learning in Croatia}

In the annual European Semester, the European Commission makes recommendations, among other things, for the prevention and correction of macroeconomic imbalances, with which Member States are expected to align their budgetary and economic policies over a six-month period. The recommendations for 2017, to which Croatia must respond with the National Reform Programme and other relevant reform documents, are given in the 2017 European Semester: Country Report-Croatia (EC, 2017).

In the document, the European Commission notes that:

- The low, and increasingly poor, level of basic skills of many students will eventually result in a lack of necessary skills within the labour market, as illustrated by the OECD's 2015 Programme for International Student Assessment (PISA) of 15-year-olds. The results for Croatian students in the study were among the worst in Europe, particularly in the fields of applied science (where the proportion of low achievers rose from $17 \%$ to $25 \%$ ) and mathematics (30\% to $32 \%)$. The OECD also highlights the fact that the proportion of students achieving top results is generally below $5 \%$, which implies problems with how able students are supported and encouraged. There has been some progress 
in the area of digital skills, with $55 \%$ of Croatian citizens having at least basic skills in 2016, an improvement on the 2015 figure of 51\%, although still below the EU average of 56\% (EC, 2017a).

- The reform of the education system, and most particularly the ambitious and comprehensive curricular reform, designed to improve teaching content and include transferable skills (learning how to learn, entrepreneurship, personal and social development, health, sustainable development, use of information and communication technologies and civic education) has been significantly delayed.

- The recovery of the labour market has revealed deficiencies across the range of skill levels of the workforce. While unemployment figures remain high in Croatia, employers in many sectors (transport, tourism, etc.) have difficulty finding suitable low to medium skilled workers, and seek increased quotas for foreign labour. There is a similar lack of higher skilled employees, for example in sectors such as ICT and healthcare, with a noted difficulty in recruiting doctors to work in rural areas, although the higher skilled workforce shows significant international mobility.

- Some positive aspects in the education system can be seen in the introduction of new qualifications in various fields, the adjustment of qualification standards and their improved alignment with the needs of the labour market. Planned improvements to the curriculum for vocational education will be based on the same methodology.

- The Croatian education system lags in re-skilling and updating the existing skills of the working population. The previously noted figures for lifelong learning $3.1 \%$ for the $25-64$ age group, compared to the EU average of $10.7 \%$ ) and the fact that $50 \%$ of the unemployed in Croatia are long-term unemployed, indicate inadequacies in lifelong learning. While legislation is being prepared to improve institutions for lifelong learning, no progress has been made towards establishing a system for recognising and validating previous learning, and resources for retraining and employer engagement with lifelong learning remain inadequate.

- There is a mismatch between higher education outputs and labour market needs. A disproportionately high number of students enrol to study social sciences and humanities in comparison with the EU average, leading to a shortage of qualified graduates with necessary skills in the science, technology, engineering and mathematics (STEM) field 
(CEDEFOP, 2016). While the introduction of enrolment quotas and carefully targeted higher education policies based on labour market needs would help to solve this problem, there is a lack of relevant data from the labour market.

It can be concluded that the further promotion of lifelong learning in Croatia is a necessary condition for the development of education, as well as for ensuring its intended economic and social outcomes.

Any analysis of participants in lifelong learning should include the number, demographics, and motives of those who participate, or the obstacles, which impede participation in education. Unfortunately, the scarcity of relevant data limits the possibility of a true analysis: while the EU's Labour Force Survey regularly monitors participation levels in lifelong education, the most recent data available from the Adult Education Survey (Eurostat, n.d.) relates to 2007, and Croatia is not a participant in the Programme for the International Assessment of Adult Competencies (PIAAC) (OECD, n.d.). Furthermore, scientific research which addresses these issues systematically remains extremely rare in the academic community. Consequently, we will begin by comparing the total number of students involved in lifelong learning in Croatia with the EU average. We will then analyse the demographics and characteristics both of students and of those who do not participate or have abandoned education.

European Commission data from 2016 (Eurostat, 2016) show that secondary school level participation in vocational education and training in Croatia is among the highest in the $\mathrm{EU}$, at $71.3 \%$. However, the employment rate for those who have recently completed secondary education $(46.1 \%$ in 2014$)$ is significantly below the EU average of 73\% (European Commission, 2016, p. 7).

Herein lies one of the major problems with the Croatian education system: the competences acquired by students throughout their schooling fail to match the competences required by the labour market. The failure to upgrade those competences presents an even more serious problem in terms of lifelong learning. Croatian adults rarely continue to upgrade their skills once they have secured employment: Eurostat data from 2016 shows that only 3.2\% of adults in Croatia participated in education and training that year (Eurostat, 2016). The research, carried out within the Labour Force Survey, involved asking persons aged between 25 and 64 whether they had participated in regular education or training activities in the four weeks before the survey (DZS, 2016). The figures for Croatia are much lower than the European average and the objectives of European and national strategies. 
Table 1: Percentage of persons aged 25 to 64 who stated that they participated in education between 2006 and 2016

\begin{tabular}{l|l|l|l|l|l|l|l|l|l|l|l}
\hline & 2006 & 2007 & 2008 & 2009 & 2010 & 2011 & 2012 & 2013 & 2014 & 2015 & 2016 \\
\hline \hline Croatia & 3.1 & 2.9 & 2.6 & 3 & 3 & 3.1 & 3.3 & 3.1 & 2.8 & 3.1 & 3.2 \\
EU & 9.6 & 9.4 & 9.5 & 9.5 & 9.3 & 9.1 & 9.2 & 10.7 & 10.8 & 10.7 & 10.8 \\
\hline
\end{tabular}

Source: http://ec.europa.eu/eurostat/web/education-and-training/data/main-tables

The figures for Croatia are relatively low, and show no significant changes in the past 10 years, varying between $2.6 \%$ and $3.2 \%$. These participation percentages are considered the main indicators of the success of lifelong learning and one of the key indicators of improvements to education systems in the period up to 2010 and in the new Europe 2020 strategy.

Although preschool education has enormous significance in terms of lifelong learning, only $72.4 \%$ of Croatian children participated in this form of education in 2015, in comparison with $94.3 \%$ for the EU as a whole, a level which presents a further problem. The implementation of Croatia's strategies within the European frameworks has led the European Commission to conclude that "participation in early childhood education and care and in adult education are extremely low compared to other EU countries" (EC, 2016).

\section{Characteristics of participants in lifelong learning in Croatia}

In the analysis of participants in lifelong learning, it is important to be aware of differences related to gender, residence and level of education. It is generally the case that there are lower levels of participation in adult education among women, people of lower educational and socioeconomic status, immigrants and the unemployed (Desjardins, Rubenson \& Milana, 2006, p. 110).

Adult education often has a tendency to reinforce inequality, the so-called "Matthew effect" adopted from Merton by education professionals (e.g., Boeren, 2009; Puljiz, 2009): "For he that hath, to him shall be given: and he that hath not, from him shall be taken even that which he hath" (The Gospel according to Matthew, 13: 12). The strategic framework for promoting lifelong learning must, therefore, target specific groups which currently have low participation levels.

The highest level of participation in adult education in Croatian in terms of employment status is attained by "inactive persons" (4.7\% of men and 5\% of women) (Eurostat, 2016). Inactive persons are, according to the ILO's definition also used by Eurostat, economically inactive persons who are not part of the 
labour force, in other words, those who are neither employed nor have unemployed status, including pupils, students, prisoners, homemakers, and pensioners (Eurostat, 2016a). Women who are employed or inactive are more frequent participants in adult education than men in the same categories, and women generally are less likely to express a wish not to be involved in adult education. The difference between these figures and the previously mentioned general trends may be accounted for by the nature of the education programmes considered in the research, and the target groups themselves. If industrial workers predominate in the group examined, there is an increased likelihood of male students, while in other cases, for example third-age education, there tends to be a predominance of female students.

Participation in adult education reaches its highest level among those with better, often managerial, positions, with the greatest percentage $(58.9 \%$ participating in some form of lifelong learning in the previous year) being for those who are more successful in their professional lives. The figure for manual workers is only $30.5 \%$ (Eurostat, 2016).

The lower the level of educational achievement, the less likely an individual is to participate in adult education, with only $7.4 \%$ of workers who fail to finish their primary education participating in adult education. This figure rises to $25.7 \%$ for those with secondary and postsecondary school education, and $61.3 \%$ for those with higher education (Eurostat, 2016). This would appear to confirm that the "Matthew effect" applies in Croatia.

An analysis of the data by age group reveals that young adults aged 25 to 34 participated most frequently in lifelong learning ( $44 \%$ in this group). Participation drops drastically with increasing age, to $37.8 \%$ in the $35-44$ age group, $33.2 \%$ in the $45-54$ age group, to only $15.7 \%$ in the $55-64$ age group in the previous year (Eurostat, 2016).

Participation in non-formal training organised by employers for their workers is $30.8 \%$, while in training organised by education and training institutions it is $20.3 \%$ (Eurostat, 2016). Location also appears to have an effect on participation in education, with $39.8 \%$ of the adult population in cities and $25.1 \%$ of the adult population in rural areas participating in education (surveyed as per the standard approach in the previous year) (Eurostat, 2016).

It is important to consider whether adult education is more effective when delivered via books or the internet. In a survey of Croatian citizen above the age of 14 , carried out in 2013 , only $48 \%$ had read at least one book in the previous year. There are some striking regional differences, with the figure rising to $62.3 \%$ in Zagreb, but as low as $27.8 \%$ in Lika, Banovina and Kordun (GfK, 2016). Although libraries have high adult membership levels, these still only represent $5 \%$ of the total adult population. 
Table 2: Library members per sex, age and active users in 2013

\begin{tabular}{l|c|c|c|l|l|l|l|l}
\hline & Total & Men & Women & \multicolumn{4}{|c|}{ Members' age } & Active users \\
\hline \hline & & & & 14 and under & $15-21$ & $22-64$ & 65 and over & \\
Total & $1,366,366$ & 593,769 & 772,597 & 467,513 & 347,242 & 508,127 & 43,484 & $1,283,922$ \\
\hline
\end{tabular}

Source: Croatian Bureau of Statistics

Computers and the internet fare somewhat better. Although keeping up with the news and sending messages are the most frequent activities involving computers, according to data from 2015, online encyclopaedias $(65 \%)$ and searches for information on education (55\%) are also popular. In 2016, for example, $14 \%$ of people bought educational materials online. Age and employment status are also factors in internet use. Almost all young people used the internet in 2016 , in comparison with only $51 \%$ of people aged 55 to $64 ; 88 \%$ of people in employment used the internet, compared to $74 \%$ of those unemployed (DZS, 2016).

The Croatian Agency for Vocational Education and Training and Adult Education (Agencija za Strukovno i Obrazovanje Odraslih - ASOO) conducted research (Vučić, Piljek Žiljak \& Vučić, 2017), in which, as many as $68.8 \%$ of respondents stated that, in the previous year, they had engaged in some form of informal learning either from books, friends, the internet, or other sources, with the internet proving to be the major learning platform (54.8\% of respondents). According to the Adult Education Survey (AES) figures, 91.9\% of Croatians are engaged in some kind of informal learning, with Cyprus the only EU Member State having a higher level of participation (96.1\%).

In order to fulfil the key objective of enabling and encouraging learning throughout life, it is necessary to identify those who abandon the process (early school leavers) and their reasons for doing so. With the lowest early school leaving rate in the $\mathrm{EU}$ ( $2.7 \%$ in 2014, the EU average being $11.1 \%)$, Croatia has already achieved the Europe 2020 strategy objective, a rate below $4 \%$.

However positive the Croatian figures might be, the European Commission has warned that this information needs to be analysed carefully, as any problems related to inclusion in and quality of primary and secondary education will continue to influence educational results, and subsequently have an impact on the labour market (EC, 2016).

For those who do leave school early in Croatia, the reasons most frequently cited are poor achievement, lack of motivation and interest in school, disciplinary problems and a poor family situation. We should also, perhaps, add low levels of parental education to the list (Matković, 2010). Other studies have identified previous poor educational achievement, low personal educational aspirations 
and resistance to school as the primary factor in leaving formal education early, with other personal traits (delinquency, addictions) as secondary factors, and the sociodemographic characteristics of the family and closer community the tertiary factors (Lemon \& Watson, 2012). Ferić, Milas \& Rihtar (2010) reinforce these factors (poor educational achievements, lack of motivation for and interest in school, disciplinary problems and poor family material situation). Teo Matković also mentions the relationship between low levels of parental education and household income on the one hand, and the increased risk of early school leaving on the other.

The analysis of early school leaving in Croatia places particular focus on the Roma and persons with disabilities. According to the results of research into the everyday life of the Roma community in Croatia (Potočnik, 2014), the inability of the education system to match the needs of "different" pupils (Potočnik, 2014 , p. 27) is an important reason, alongside "tradition and school leaving culture" for early school leaving. A significant number of Roma children leave school at the age of 15 , when the obligation to attend education ceases, in many cases thereby effectively abandoning mandatory education, as failing a grade means they are unlikely to have completed all eight grades (ibid, p. 48). While the number of Roma children in secondary schools is increasing (503 in 2014), as a rule, the number of Roma pupils drops by between $5 \%$ and $10 \%$ over the course of the school year (Potočnik, 2014). Furthermore, only 44\% of Roma children attend preschool, substantially lower than the average, of whom only $40 \%$ will go on to finish primary school, and only $9 \%$ to finish secondary school. In the academic year 2011/12, there were only 29 Roma students in higher education (Potočnik, 2014 , p. 53). Furthermore, the average Roma adult (aged 25 - 64) will have spent six fewer years in education than non-Roma persons. Roma women are particularly disadvantaged in this area, having on average two fewer years of education than Roma men, and almost seven fewer than their non-Roma peers. However, the younger generation is becoming better educated as, on average, they complete two years of education more than the overall Roma population, and the gender differences are less pronounced (Potočnik, 2014, p. 49).

According to Eurostat, there is a high number of people with disabilities in the NEET group (Not in Education, Employment, or Training) for people between the ages of 18 and 24 (Eurostat, 2016c). Of these, 63\% have completed only primary education, some of them not even attaining that level. Approximately $28 \%$ have completed secondary education, but only $3 \%$ have graduated from higher education establishments (Benjak, 2016). The trend for early school leaving for people with disabilities is lower in Croatia than the European average, but problems exist over the ongoing transition from special schools to inclusive 
education, harmonisation of the professional profiles for which people with disabilities are educated with the labour market's needs, and the low number who continue into tertiary education.

\section{Obstacles to participation in lifelong learning in Croatia}

Rubenson (2011) defines obstacles to participation in adult education under three categories: situational, institutional and dispositional. Situational obstacles occur when real life situations arise which could prevent a person's participation in education; for example, the situation at work, family circumstances, lack of free time, etc. Institutional obstacles refer to the procedures or rules of an educational institution which can discourage or prevent an individual from joining the educational cycle. According to Rubenson, dispositional obstacles refer to a person's attitudes and self-perception, how he/she perceives himself/herself as a possible student. A readiness to learn and previously acquired competences are also relevant to this obstacle. Lack of confidence is one of the most significant obstacles to participation in education. The European Commission's 2012 European strategy for improving participation in and awareness of adult learning similarly categorises obstacles as structural, situational and psychological (EC, 2012).

According to the 2016 AES (Eurostat, 2016), the most prominent obstacles to participation in adult education of persons aged 25 to 64 in Croatia are:

- $\quad$ no perceived need for further education and training (53.9\%);

- programme are costs too high (10.9\%);

- lack of time due to family obligations (7\%).

The significance of the latter two as fundamental obstacles to learning is reiterated in the results of research conducted by ASOO and the research agency IPSOS Puls: cost of education (30.2\%), lack of time (27.8\%) (Vučić, Piljek Žiljak, Vučić, 2017, p. 30).

Health-related obstacles are a significant problem for older members of the population in Croatia, being a factor preventing participation for $39.4 \%$ of those aged between 55 and 64, but for only 14\% in the total population aged between 25 and 64. Conversely, the cost of education is less of an obstacle for the elderly (34.5\% in the 55 to 64 age group) than for younger people ( $44.1 \%$ for those aged 35 to 44). Family obligations are a more considerable obstacle for women (Eurostat, 2016).

In $87 \%$ of cases, those who had attained only the most basic level of formal education (primary school) stated that they had no wish to participate in adult 
education (Eurostat, 2016). Previous experience of education is an important factor in participation in learning: it is not, however, limited to the quality of teaching, but, rather, encompasses all aspects of life during education. According to the latest AES study (2016), 22.1\% of participants in adult education do not wish to participate further, while only $5.5 \%$ wish to participate again. The number of potential participants is much higher among those who have no experience of adult learning (54.1\%) (Eurostat, 2016).

A study carried out by ASOO (Vučić, Piljek Žiljak \& Vučić, 2017) shows that cognitive motives (a wish to learn something new) are the most important for educational participation, followed by motives related to keeping an existing job, or finding a new one. Participants with lower educational achievements are generally motivated by formal, job-related requirements, or the requirements of the labour market.

\section{Strategy for promotion of lifelong learning in Croatia}

\section{The pillars of strategic orientation to the promotion of lifelong learning}

The vision and values of lifelong learning in Croatian society, as already expressed, necessitate the raising of awareness of the civic role of lifelong learning as a positive value, and the creation of a positive and active attitude towards learning at any age in all stakeholders in society The following objectives in raising awareness of the significance of lifelong learning are implied:

- Change of attitude toward learning - learning is about more than gaining skills; it is also about personal and social development, creativity and entrepreneurship. Learning, life, business and cultural experiences prepare an individual for an active life, develop the power of reasoning, the ability to analyse the living environment and one's place in it, and allow for the possibility of self-realisation.

- Comprehensive learning opens new possibilities - as the learning environment widens, so it moves beyond the formal or school context and begins to encompass learning opportunities which occur throughout life, regardless of age and social status. Outside the formal and organised learning contexts, an individual learns in the workplace, at home, through hobbies and volunteering, and in so doing learns to govern his/her own life, make life decisions and attain prosperity. 
- Renewal of knowledge - the achievement of social inclusion, a good quality of life and prosperity requires the constant renewal of the knowledge relevant to an individual's work, and also their social role. For adults, this means satisfying labour market needs, especially for those adults who are at risk of losing their jobs and being excluded from the labour market.

- Raising awareness of the direct link between knowledge and skills and a labour market position and employment opportunities.

Once an awareness of the benefits of lifelong learning has been established, it is necessary to provide information about the possibilities of lifelong learning, which can be achieved by:

- providing structured information about the possibilities of learning;

- engaging all social actors/stakeholders in planning and promotion, as well as the overall marketing effort to make lifelong learning attractive;

- providing appropriate introductory experiences to lifelong learning (EC, 2015).

A key role in the promotion of lifelong learning must involve the provision of appropriate information and counselling to target groups. Information points and centres where individuals may access professional counselling and career orientation, along with other useful material, are currently provided by the Croatian Employment Service (CES). Advisers employed at the CES use various means, such as individual, group, on-line and telephone counselling and orientation services to help their clients explore, pursue and attain their career-related goals. In such a process, it is crucial to raise the individual's self-awareness, and awareness of his/her own interests, strengths and weaknesses, and to increase understanding of the importance of continuous self-improvement and enable self-management of the processes for learning and acquiring new knowledge and skills, as well as encouraging positive career changes.

Alongside CES materials, various forms of information and counselling associated with further education, being competitive in the labour market, and career development are available in primary and secondary schools, higher educational institutions and institutions for adult learning, although it should be noted that variations in the capacities and resources of the providing institutions lead to considerable differences in their availability and quality, making it impossible to talk about systematic professional orientation. Civil society organisations also provide information and counselling services, often targeted at specific groups, 
for example, the young, national minorities, socially vulnerable groups, pupils and students with disabilities, although again their availability and quality are conditional upon the capacities and resources of the organisations.

The Strategy for Lifelong Career Guidance in the Republic of Croatia (EC, 2016a) is both complementary to the objectives of the promotion of, and crucial for information on the possibilities of, lifelong learning. The main objective of this Strategy in the period up until 2020 is to establish a "complete system for lifelong professional orientation which will enable the availability of a goodquality professional orientation service to citizens to develop their career in accordance with their abilities, interests, personality traits and labour market needs throughout their lives" (EC, 2016a). The Strategy requires that lifelong professional orientation be directed to the needs of individual users, and be impartial, available, and provide equal possibilities to everyone in order to satisfy the needs of different citizens. This focus on the professional orientation of the individual is recognised in the Strategy as generating much wider economic benefits by connecting the goals of the individual with wider economic and social goals within Croatia as a whole.

Consequently, as noted by the Strategic framework for promotion of lifelong learning in the Republic of Croatia:

It is crucial that advisers in the process of lifelong professional orientation are educated experts who are able to recognise the clients' competences and direct them toward the acquisition of new knowledge and skills with the aim of personal and professional development and improved chances of employment. (Vučić, Alfirević \& Pavičić, 2017, p. 35)

A further problem for lifelong learning in Croatia is the insufficient harmonisation of the education system and the labour market. It is notable that discrepancies in the measurement of over qualification are lowest for tertiary education (professional study - between $47.1 \%$ and $55 \%$, academic study - between $32.5 \%$ and $38.4 \%$ ), and that the disparity between the occupation for which a person was educated and the occupation of first employment is found by the survey to be $41.5 \%$. The highest levels of this disparity were found to occur for three-year $(40.2 \%)$ and four-year $(54.3 \%)$ vocational education courses, while these indicators are considerably lower for tertiary education (professional study, $38.2 \%$, academic study, 28.7\%).

Conversely, the general picture of education in Croatia shows a relatively high level of formal educational attainment, indicating that domestic education policy has been successful in raising the formal level of education in the country, 
as can be seen in comparisons with European national averages, and between younger and older sectors of the population (see Table 3 ).

Table 3: Educational achievements in the EU 2016

\begin{tabular}{|c|c|c|c|c|c|c|}
\hline & \multicolumn{3}{|c|}{$25-54$ years } & \multicolumn{3}{|c|}{ 55-74 years } \\
\hline & $\begin{array}{l}\text { Low } \\
\text { (ISCED 0-2) }\end{array}$ & $\begin{array}{l}\text { Medium } \\
\text { (ISCED 3-4) }\end{array}$ & $\begin{array}{l}\text { High } \\
\text { (ISCED 5-8) }\end{array}$ & $\begin{array}{l}\text { Low } \\
\text { (ISCED 0-2) }\end{array}$ & $\begin{array}{l}\text { Medium } \\
\text { (ISCED 3-4) }\end{array}$ & $\begin{array}{l}\text { High } \\
\text { (ISCED 5-8) }\end{array}$ \\
\hline EU-28 & 20.5 & 46.2 & 33.4 & 36.3 & 43.1 & 20.6 \\
\hline EA-19 & 23.4 & 44.3 & 32.3 & 40.8 & 39.0 & 20.2 \\
\hline Belgium & 20.4 & 38.9 & 40.7 & 42.8 & 31.6 & 25.6 \\
\hline Bulgaria & 16.9 & 54.0 & 29.1 & 26.0 & 52.9 & 21.1 \\
\hline Czech Republic & 5.4 & 69.4 & 25.2 & 12.1 & 73.7 & 14.2 \\
\hline Denmark & 16.9 & 42.5 & 40.6 & 29.7 & 43.2 & 27.1 \\
\hline Germany & 13.2 & 57.8 & 29.0 & 16.0 & 58.6 & 25.4 \\
\hline Estonia & 10.6 & 49.6 & 39.7 & 17.1 & 48.3 & 34.6 \\
\hline Ireland & 15.4 & 37.5 & 47.1 & 45.9 & 30.2 & 23.9 \\
\hline Greece & 22.8 & 44.1 & 33.0 & 54.8 & 27.5 & 17.7 \\
\hline Spain & 37.4 & 23.5 & 39.2 & 64.9 & 15.3 & 19.8 \\
\hline France & 17.7 & 43.7 & 38.7 & 38.9 & 40.2 & 20.9 \\
\hline Croatia & 12.8 & 61.6 & 25.5 & 32.7 & 49.9 & 17.4 \\
\hline Italy & 36.2 & 44.4 & 19.4 & 59.5 & 29.7 & 10.8 \\
\hline Cyprus & 16.4 & 37.9 & 45.7 & 43.8 & 32.7 & 23.5 \\
\hline Latvia & 9.7 & 54.8 & 35.5 & 13.4 & 62.0 & 24.6 \\
\hline Lithuania & 5.7 & 51.5 & 42.8 & 11.2 & 62.1 & 26.7 \\
\hline Luxembourg & 19.0 & 34.5 & 46.5 & 33.4 & 40.2 & 26.4 \\
\hline Hungary & 14.9 & 59.2 & 25.9 & 26.1 & 57.0 & 16.8 \\
\hline Malta & 48.8 & 27.3 & 23.9 & 76.7 & 14.9 & 8.4 \\
\hline Netherlands & 19.3 & 41.9 & 38.8 & 39.1 & 36.1 & 24.8 \\
\hline Austria & 13.7 & 52.4 & 33.9 & 242 & 54.4 & 21.4 \\
\hline Poland & 6.8 & 59.3 & 33.9 & 19.3 & 66.6 & 14.1 \\
\hline Portugal & 46.4 & 26.3 & 27.3 & 79.4 & 9.7 & 10.9 \\
\hline Romania & 20.9 & 59.2 & 19.8 & 41.5 & 50.1 & 8.5 \\
\hline Slovenia & 9.7 & 55.7 & 34.6 & 23.3 & 58.1 & 18.5 \\
\hline Slovakia & 6.6 & 69.0 & 24.4 & 16.2 & 70.3 & 13.6 \\
\hline Finland & 9.7 & 45.0 & 45.3 & 26.2 & 40.2 & 33.6 \\
\hline Sweden & 12.6 & 43.2 & 44.2 & 27.3 & 43.6 & 29.1 \\
\hline United Kingdom & 18.6 & 36.7 & 44.7 & 29.3 & 38.0 & 32.7 \\
\hline Iceland & 19.7 & 36.4 & 44.0 & 32.6 & 41.8 & 25.6 \\
\hline Norway & 16.9 & 37.0 & 46.1 & 20.8 & 48.6 & 30.5 \\
\hline Switzerland & 10.5 & 43.2 & 46.2 & 16.6 & 53.0 & 30.4 \\
\hline
\end{tabular}




\begin{tabular}{|c|c|c|c|c|c|c|}
\hline & \multicolumn{3}{|c|}{$25-54$ years } & \multicolumn{3}{|c|}{ 55-74 years } \\
\hline & $\begin{array}{l}\text { Low } \\
\text { (ISCED 0-2) }\end{array}$ & $\begin{array}{l}\text { Medium } \\
\text { (ISCED 3-4) }\end{array}$ & $\begin{array}{l}\text { High } \\
\text { (ISCED 5-8) }\end{array}$ & $\begin{array}{l}\text { Low } \\
\text { (ISCED 0-2) }\end{array}$ & $\begin{array}{l}\text { Medium } \\
\text { (ISCED 3-4) }\end{array}$ & $\begin{array}{l}\text { High } \\
\text { (ISCED 5-8) }\end{array}$ \\
\hline $\begin{array}{l}\text { FYR of } \\
\text { Macedonia }\end{array}$ & 28.5 & 49.1 & 22.4 & 472 & 38.3 & 14.5 \\
\hline Turkey & 61.0 & 19.2 & 19.8 & 83.7 & 8.8 & 7.5 \\
\hline
\end{tabular}

Source: Eurostat, http://ec.europa.eu/eurostat/statistics-explained/index.php/Educational_attainment_statistics

In order to more effectively promote lifelong learning in Croatia, it is clear that less attention should be paid to encouraging the attainment of formal educational achievements. The fundamental intention of educational reforms on the basis of the introduction of the Croatian Qualifications Framework (CQF) (VRH, 2016) must be to address the insufficient harmonisation of the functioning of the education system and labour market needs. Unfortunately, the initial $\mathrm{CQF}$ projects have been limited to providers of tertiary level education services, i.e. on the (re)structuring of the curricula of higher educational institutions, and not on the basic harmonisation problem at lower levels. Making information about the CQF easily and readily available and motivating participants to attend programmes based on CQF principles are the project aspects which have not yet been sufficiently addressed.

As has been previously illustrated, the participation of adults in lifelong learning in Croatia is extremely low, at only $3.2 \%$ in 2016, a figure which should be viewed in the context of the EU goal of achieving $15 \%$ participation by 2020 . This figure reiterates the need to increase both the motivation to participate in and the competences required for lifelong learning among Croatian adults, even though the 3.2\% participation rate may be challenged by the results of the latest empirical research conducted by ASOO (Vučić, Alfirević \& Pavičić, 2017).

The Strategy of Education, Science and Technology of the Republic of Croatia (VRH, 2014) also anticipates that a system will be needed for the recognition of knowledge and skills acquired through non-formal and informal learning, alongside qualifications gained from formal education. The foundations for the development of such a recognition system are laid down in the Croatian Qualifications Framework Act (VRH, 2016). The Ordinance on Recognition and Evaluation of Non-Formal and Informal Learning, which is currently being drafted, will define the recognition procedures for previous learning. As the focus of the Croatian Qualifications Framework (CQF) is on learning outcomes, rather than the process or environment which produces those outcomes, the assumption that certain learning outcomes can be achieved outside formal education necessitates the crea- 
tion of a system of evaluation for non-formally and informally achieved learning outcomes under the same principles as those achieved under formal conditions.

\section{Priorities and objectives of the promotion of lifelong learning in Croatia}

Two key areas need to be targeted under the priorities and objectives of the promotion of lifelong learning in Croatia: increasing competitiveness in the labour market and the affirmation of personal and social growth and development through lifelong learning.

Content determinants for increasing competitiveness in the labour market are as follows:

- the need to continuously renew knowledge and acquire new skills, with the aim of increasing one's employability and chances in the labour market;

- the need to form attitudes and opinions regarding the importance of knowledge, skills and competences as a path towards employment and prosperity.

For the affirmation of personal growth and development, the content determinants are:

- raising awareness of the personal benefits of learning and the importance of personal initiative for learning:

- raising awareness of the importance of acquiring all the key competences, especially digital skills, enterprise and innovativeness in modern society.

Key target groups will be selected for promotional activities for lifelong learning, and the following common principles will be used when planning these activities:

- communication of the advantages and benefits of lifelong learning will be at the heart of all promotional activities, with the information adjusted to the specificities and needs of the different target groups;

- specific implementation measures will be integral to all the activities, for example national and local information centres which will provide information on the possibilities of inclusion into various forms of lifelong learning, national and local campaigns and examples of good practice adjusted to each target group. 


\section{Using marketing tools in the promotion of lifelong learning and development of targeted communication plans}

Different theoretical perspectives (Oplatka, 2016) criticise educational marketing for treating education as a commodity to be commercialised and 'marketised', as opposed to valuing its intrinsic human values. Nevertheless, the marketing of educational services has become common practice, especially in higher education (Hemsley-Brown \& Oplatka, 2006). In compulsory education, increased competition (direct or indirect) entices educational leaders to use marketing tools to achieve a higher level of 'market share' (i.e. to assist in recruiting new students), attract external funding, and achieve a better relationship with the stakeholders of an educational institution, etc. (Oplatka \& Hemsley-Brown, 2004).

There is no universally accepted definition of school/educational marketing, although most of it currently in existence draws on commercial sector marketing concepts, and emphasises the exchange of value between an educational institution and students, as well as other stakeholders. The marketing process should lead to stakeholder satisfaction and the realisation of institutional objectives. Marketing practices are, as a rule, oriented toward understanding the trends in the external environment and the needs of the organisational clients, as to create relevant responses to those challenges and to implement them across the organisation (Kohli \& Jaworski, 1990). This widely accepted theory is referred to as market orientation, and proves to be applicable in educational institutions as well. Some authors believe that market orientation represents a significant aspect of school (organisational) culture, with educational leaders being responsible for its development (Oplatka \& Hemsley-Brown, 2007). This is to be achieved by practising democratic leadership, by serving as a role model in the field of understanding and responding to the stakeholders' needs, and by selecting teachers/ staff who are ready and willing to serve the same needs.

Although many different studies have analysed the 'marketisation' of education, few have tackled the challenges of marketing rhetoric and practice in further education and education policy. Some participants in the discussion of marketing higher and further education institutions may wish to develop a balance between the practical benefits of marketing practice (such as the flexibility and increased efficiency of educational institutions) and the traditional notions of knowledge as a value per se and education as a human practice (Newman \& Jahdi, 2009). In the policy field, critical voices are examining the influences of actors on educational policy and its outcomes (Ball, 2012), acknowledging economic and other interests as active policy drivers. 
Unfortunately, the existing literature does not seem to recognise the applicability of widely accepted aspects of marketing (including the orientation toward satisfying clients' needs and the achievement of flexibility and efficiency in the educational process) in the field of promoting adult/lifelong learning. The authors of this article and the related Croatian policy recommendations (Vučić, Alfirević \& Pavičić, 2017) have used the traditional concept of promotion (considered to be a part of the fundamental marketing mix) to influence the motivation of adult/lifelong learners and assist the work of all relevant Croatian stakeholders to engage in the promotion of adult/lifelong learning.

In this context, motivation for lifelong learning has been considered to be a much wider social process than is the case in the existing literature on education psychology (McCombs, 1991) and education science (Brookfield, 1986). The motivational processes are, in the authors' view, not restricted to the individual motivation to learn and the psychological intervention used to develop such motivation. The potential tools and approaches for the facilitation of learning are more comprehensive than the design of a relevant support process at a single educational institution, or even a group of them. The successful facilitation of learning should be closely associated with a range of social and economic tools/ approaches needed to remove the obstacles to lifelong learning and support individuals in their intention to keep learning, even if their first attempts to engage in lifelong learning might not be entirely successful. To implement such an approach, a national consensus related to the value of lifelong learning is required, along with an effort to develop lasting cooperation among all the relevant stakeholders of both formal and informal education.

The recommendations issued to the institutional actors in Croatia (Vučić, Alfirević \& Pavičić, 2017), on the presumption that ASOO has a central role as a coordinating and advisory body, could also be successfully implemented across the South-East European region. Similar tools/instruments could be derived, as to develop the promotion of lifelong learning in completely different contexts and environments, although they should apply the same marketing principles used in this specific case. These include:

- orientation toward specific client groups (i.e. target groups) and their inherent needs, as implied by the notion of target 'markets' within the marketing concept itself (Kotler, 1972);

- the generic objectives of the promotion process in marketing, which are usually formulated in terms of informing, persuading and reminding members of the targeted group(s) to engage in a certain form of behaviour; 
- the use of the most appropriate communication tools and approaches (as determined by the characteristics of the target group) to raise awareness (i.e. create attention), provide information about educational opportunities (leading to interest), and develop motivation for participation in lifelong learning (i.e. ensure desire and action in lifelong learners). This accords with the classical AIDA model of consumer behaviour, an overview of which is given by Barry \& Howard (1990).

\section{Generic recommendations for the promotion of lifelong learning}

Based on the principles outlined above, the authors have developed a set of four generic recommendations for the promotion of lifelong learning. They are as follows:

1. Various types of education (vocational and non-vocational; formal and non-formal) and informal learning are all a part of the lifelong learning process, which lasts throughout an individual's entire lifetime, and refers to the acquisition of all the competences an individual needs to fulfil different roles. Everyone participating in different forms of lifelong learning can be defined as a user or a participant in this process.

2. Those who join the learning process after completing regular education should receive particular attention. The acquisition of assumptions about continuous learning in regular education and the continuation of learning within intergenerational cooperation after the age of 64 is important. Special attention and incentives should be directed toward those who do not currently join the lifelong learning processes. This primarily applies to people with lower educational levels, the long-term unemployed, people who live in rural areas, elderly people, manual workers with difficult jobs, and members of vulnerable groups, especially the Roma and persons with disabilities.

3. The clear demonstration of the personal, social, economic and community benefits of lifelong learning is central to its promotion. The greatest emphasis is on new skills for new jobs and development associated with innovation. Aside from the predominance of learning for the labour market, all forms of learning which enable the free development of individuals, strengthening their civic roles, their 
appreciation of society, their intergenerational cooperation and their satisfaction with the process itself are also important.

4. The aim of the promotion of lifelong learning is to influence key actors whose subsequent actions can eliminate obstacles to inclusion into lifelong learning, in particular structural and situational obstacles. It is important to familiarise decision-makers at national, regional and local levels with all aspects of the execution of and benefits from lifelong learning. Moreover, it is important to enhance awareness that, by eliminating obstacles and further motivating citizens, it is possible to increase participation in lifelong learning, the low level of which is already recognised as a considerable problem in Croatia. Promotion should commence in institutions of early and preschool education, continue in primary and secondary schools, and finally be present in higher education and adult educational institutions.

\section{References}

Aspin, D. N., \& Chapman, J. D. (Eds.). (2007). Values education and lifelong learning: Principles, policies, programmes (Vol. 10). Dordrecht: Springer Science \& Business Media.

BALl, S. J. (2012). Politics and policy making in education: Explorations in sociology. Oxford: Routledge.

BARry, T. E., \& HowARD, D. J. (1990). A review and critique of the hierarchy of effects in advertising. International Journal of Advertising, 9(2), 121-135.

Benjak, T. (2016). Report on persons with disability in the Republic of Croatia. Zagreb: Croatian Institute of Public Health.

Boeren, E. (2009). Adult education participation: the Matthew principle. Filosofija. Sociologija, 20 (2), 154-161.

Brookfield, S. (1986). Understanding and facilitating adult learning: A comprehensive analysis of principles and effective practices. McGraw-Hill Education (UK).

Croatian Bureau of Statistics [DZS] (2015). Statistical yearbook 2015. Zagreb: Author. Retrieved from http://www.dzs.hr/Hrv_Eng /ljetopis/2015/sljh2015.pdf

Croatian Bureau of Statistics [DZS] (2016). Results of the Labour Force Survey Croatia 2015 - Europe 2015, Statistical reports. Retrieved from http://www.dzs.hr/Hrv_ Eng/publication/2016/SI-1575.pdf

Desjardins, R., Rubenson, K., \& Milana, M. (2006). Unequal chances to participate in adult learning: International perspectives (No. 83). International Institute for Educational Planning (IIEP) UNESCO. 
European Centre for the Development of Vocational Training [CEDEFOP] (2016). Mismatch priority occupations Croatia. Retrieved from http://skillspanorama. cedefop.europa.eu/en/analytical_highligths/croatia-mismatch-priority-occupations

European Commission (2000). A memorandum on lifelong learning. Brussels: European Commission

European Commission (2006). Adult learning: It is never too late to learn. Brussels: European Commission.

European Commission. (2012). European Guide - Strategies for improving participation in and awareness of adult learning. Brussels: European Commission.

European Commission. (2015). An in-depth analysis of adult learning policies and their effectiveness in Europe. Luxembourg: Publications Office of the European Union.

European Commission. (2016). Overview of education and training for 2016. Education in Croatia. Luxembourg: Publications Office of the European Union. Retrieved from https://ec.europa.eu/education/sites/education/files/monitor2016-hr_hr.pdf

European Commission. (2016a). Strategy for lifelong career guidance in the Republic of Croatia 2016-2020. Retrieved from https://ec.europa.eu/epale/sites/epale/files/ strategija_cpu_eng_kon.pdf

European Commission. (2017). Country report Croatia 2017, Including an in-depth review on the prevention and correction of macroeconomic imbalances. Retrieved from https://ec.europa.eu/info/sites/info/files/2017-european-semester-countryreport-croatia-en.pdf

European Commission. (2017a). Digital economy and society index. Retrieved from http://ec.europa.eu/newsroom/document.cfm?doc_id=42995

European Commission. (2017b). Overview of education and training for 2016. Education in Croatia. Luxembourg: Publications Office of the European Union. Retrieved from https://ec.europa.eu/education/sites/education/files/monitor2017-hr_en.pdf

European Commission. (n.d.). Promoting Adult Learning. Retrieved from https:// ec.europa.eu/education/policy/adult-learning/adult_en.

Eurostat. (2016). Education and training (Database) (numerous charts). Retrieved from http://ec.europa.eu/eurostat/data/database/

Eurostat. (2016a). Glossary. Retrieved from http://ec.europa.eu/eurostat/statistics-explained/index.php/Glossary:Inactive

Eurostat. (n.d.). Labour market and lifelong learning. Retrieved from http://ec.europa. eu/eurostat/cache/metadata/en/trng_aes_12m0_esms.htm

Ferić, I., Milas, G., \& Rihtar, S. (2010). Razlozi i odrednice ranoga napuštanja školovanja (Reasons and determinants of early education leaving). Društvena istraživanja, 19(4-5), 108-109.

Gesellschaft für Konsumforschung. (2016). Survey of the book market in Croatia. Zagreb: Author.

Government of the Republic of Croatia [VRH]. (2007). Adult education act (2007). Official Gazette 17/07, 107/07, 24/10.

Government of the Republic of Croatia [VRH]. (2012). National strategy of creating an enabling environment for civil society development from 2012 to 2016. Re- 
trieved from https://udruge.gov.hr/UserDocsImages/UserFiles/File/National\%20 Strategy-Civil\%20Society-Croatia-2012-2016-eng.pdf

Government of the Republic of Croatia [VRH]. (2013). Croatian qualifications framework act, Official Gazette, 22/2013, 41/2016.

Government of the Republic of Croatia [VRH] (2013a). Vocational education act (2013). Official Gazette, 30/09, 24/10, 22/13.

Government of the Republic of Croatia [VRH]. (2014). Strategy of science, education and technology. Retrieved from https://mzo.hr/sites/default/files/dokumenti/ Strategija_OZT/Strategy_eng/strategy_for_education_science_and_technology. pdf

Government of the Republic of Croatia [VRH]. (2016). Revised strategic plan of the Ministry of Labour and Pension System 2016-2018. Retrieved from http:// www.mrms.hr/wp-content/uploads/2016/05/STRATE\%C5\%A0KI-PLANMRMS_2016_2018.pdf.

Government of the Republic of Croatia [VRH]. (2016a). VET System Development Programme. Retrieved from https://public.mzos.hr/fgs.axd?id=25751

Hemsley-Brown, J., \& Oplatka, I. (2006). Universities in a competitive global marketplace: A systematic review of the literature on higher education marketing. International Journal of Public Sector Management, 19(4), 316-338.

Kohl, A. K., \& Jaworski, B. J. (1990). Market orientation: the construct, research propositions, and managerial implications. The Journal of Marketing, 54(2), 1-18.

Kotler, P. (1972). A generic concept of marketing. The Journal of Marketing, 36(2), 46-54.

Lemon, J. C., \&Watson, J. C. (2012). Early Identification of Potential High School Dropouts: An Investigation of the relationship among at-risk status, wellness, perceived stress, and mattering. The Journal of At-Risk Issues, 16(2), 17-25.

Matкović, T. (2010). Obrazovanje roditelja, materijalni status i rano napuštanje školovanja u Hrvatskoj: trendovi u proteklom desetljeću (Parental education, material status and early education leaving in Croatia: Trends in the last decade). Društvena istraživanja, 19(4-5): 643-667.

McСombs, B. L. (1991). Motivation and lifelong learning. Educational Psychologist, 26(2), 117-127.

Newman, S., \& Jahdi, K. (2009). Marketisation of education: Marketing, rhetoric and reality. Journal of Further and Higher Education, 33(1), 1-11.

NóvoA, A (2013). The blindness of Europe: New fabrications in the European educational space. Sisyphus Journal of Education, 1(1),104-123.

Oplatka, I., \& Hemsley-Brown, J. (2004). The research on school marketing: Current issues and future directions. Journal of Educational Administration, 42(3), 375400.

Oplatka, I. (2016). Teachers' perceptions of their role in educational marketing: Insights from the case of Edmonton, Alberta. Canadian Journal of Educational Administration and Policy, 51. 
Oplatka, I., \& Hemsley-Brown, J. (2007). The incorporation of market orientation in the school culture: An essential aspect of school marketing. International Journal of Educational Management, 21(4), 292-305.

Organization for Economic Cooperation and Development [OECD] (n.d.). Programme for the International Assessment of Adult Competencies (PIAAC). Retrieved from http://www.oecd.org/skills/piaac

Ротос̌niк, D. (Ed.) (2014). Roma everyday life in Croatia: Challanges and opportunities for change. Zagreb: UNDP / UNHCR / UNICEF.

Puljiz, V. (2009). Obrazovanje i "učinak svetog Mateja" (Education and "the Mathew effect"). Revija za socijalnu politiku, 16(2), 200-201.

Rubenson, K. (2011). Barriers to Participation in Adult Education. In K. Rubenson (Ed.), Adult learning and education (216-223). Oxford: Elsevier.

Schuetze, H. G., \& Casey, C. (2006). Models and meanings of lifelong learning: Progress and barriers on the road to a learning society. Compare, 36(3), 279-287.

Vučić, M., Alfirević, N., \& PAvičić, J. (Eds.) (2017): Strategic framework for promotion of lifelong learning in the Republic of Croatia 2017-2021. Zagreb: Agency for Vocational Education and Training and Adult Education. Retrived from https:// ec.europa.eu/epale/sites/epale/files/strateski_okvir_engl_priprema.pdf

Vučić, M., Piljek ŽılujaK, O., \& VučIĆ, N. (Eds.) (2017): Obrazovanje odraslih u Hrvatskoj 2017 - Rezultati istraživanja (Adult education in Croatia 2017 - Research results). Zagreb: Agency for Vocational Education and Training and Adult Education. Retrived from http://www.cjelozivotno-ucenje.hr/wp-content/uploads/2017/10/ ASOO_Obrazovanje-odraslih_report_za_web.pdf 
Tihomir Žiljak ${ }^{6}$

Pučko otvoreno učilište u Zagrebu, Hrvatska

Nikša Alfirević ${ }^{7}$

Ekonomski fakultet u Splitu, Hrvatska

Jurica Pavičićc

Sveučilište u Zagrebu, Ekonomski fakultet, Hrvatska

Mario Vučić 9

Agencija za strukovno obrazovanje i obrazovanje odraslih, Hrvatska

\section{Promocija stručnog učenja i učenja odraslih u Hrvatskoj: rezultati inicijativa vođenih obrazovnom politikom i generičke implikacije za obrazovnu politiku i praksu u jugoistočnoj Evropi}

Apstrakt: U ovom članku autori predstavljaju i analiziraju skorašnje preporuke obrazovne politike za promociju stručnog učenja i učenja odraslih u Hrvatskoj. Autori uz to predstavljaju i argumente u korist šireg učešća interesnih grupa i nude neke smernice za implementaciju marketinških principa u promociju učenja. U članku se takođe identifikuju određene generičke implikacije za slične inicijative u jugoistočnoj Evropi.

Ključne reči: celoživotno učenje, promocija, Hrvatska.

\footnotetext{
${ }^{6}$ Dr Tihomir Žiljak je šef Odseka za celoživotno učenje, razvoj i programe Evropske unije na Pučkom otvorenom učilištu u Zagrebu, docent na Sveučilištu u Zagrebu u Hrvatskoj i Mostaru u Bosni i Hercegovini.

${ }^{7}$ Dr Nikša Alfirević je profesor na Ekonomskom fakultetu Sveučilišta u Splitu u Hrvatskoj i istraživački radnik Znanstvenog centra izvrsnosti za školsku efektivnost i menadžment.

${ }^{8}$ Dr Jurica Pavičić je profesor i prodekan na Ekonomskom fakultetu Sveučilišta u Zagrebu u Hrvatskoj i glavni istraživački radnik Znanstvenog centra izvrsnosti za školsku efektivnost i menadžment.

${ }^{9}$ Mario Vučić je pomoćnik direktora za razvoj obrazovanja odraslih pri Agenciji za strukovno obrazovanje i obrazovanje odraslih u Hrvatskoj.
} 